\title{
The Association Of Body Mass Index And Prostatic Cancer Histopathological Grade
}

\author{
Marwa Muzahim Fattah*, Adil Siwan AL-Aqabi** \\ *Oncology Teaching Hospital , Mosul , **Baghdad Teaching Hospital , Department of \\ Hematology , Baghdad , Iraq \\ Correspondence: marwa.muzahim86@gmail.com
}

(Ann Coll Med Mosul 2021; 43 (2):139-143).

Received: $3^{\text {rd }}$ July 2021; Accepted: $27^{\text {th }}$ Sept. 2021.

\begin{abstract}
Background: Obesity, a global public health concern, has been repeatedly linked to the development of different cancers in epidemiologic and basic research studies, Prostate cancer is the most frequently encountered solid tissue cancer in men. Gleason score of the prostate cancer is one of the most important parameter, which provides the most important data about biological behavior of the cancer and affect on the selection of the treatment and its outcomes. Therefore, accuracy of Gleason score, based on histopathological analysis of the biopsy material, has a critical importance

Patients and Methods: A cross-sectional study with retrospective analytical elements, among prostate cancer patients who were diagnosed based on histopathology of prostate gland, then classified accorrding to G.S (gleasson score) and body mass index.
\end{abstract}

Aim of this study: To evaluate the association between high body mass index and Gleason grade of prostate cancer.

Results: The results of this study showed that patients with high body mass index Significantly associated with high grade of prostate cancer, as $(46.4 \%$ and $62.2 \%$ of overweight and obese patients respectively had high Gleason score above 7 while $12.5 \%$ of overweight and $8.1 \%$ of obese patients had low Gleason score and the $p$ Value was (0.002).

Conclusion: This study found that high body mass index associated with increase high grade of prostate cancer.

Keywords: BMI : body mass index, G.S : gleasson score , prostate cancer .

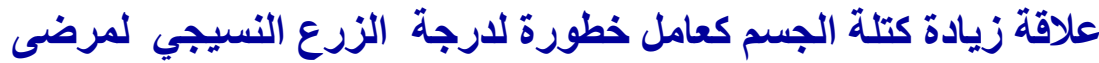

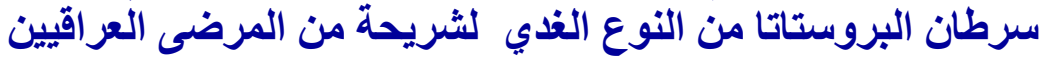

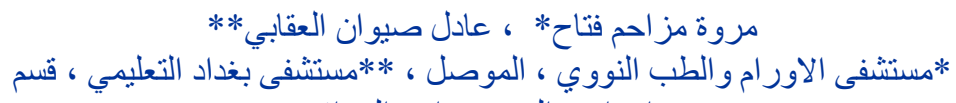

$$
\begin{aligned}
& \text { امر اض الدم ، بغداد ، العراق لاق }
\end{aligned}
$$

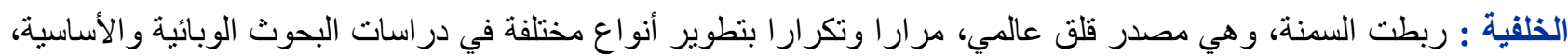

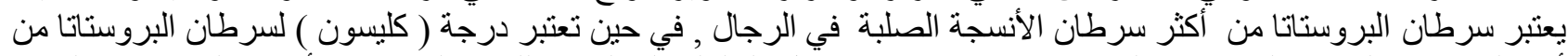

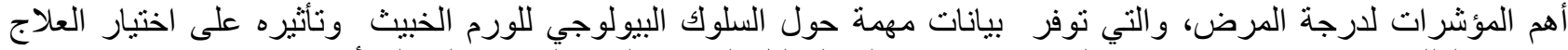

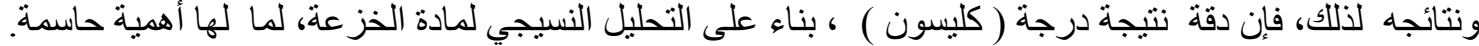

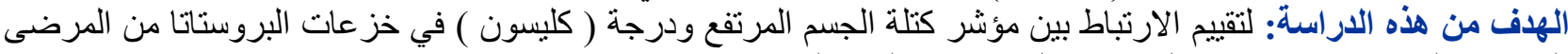

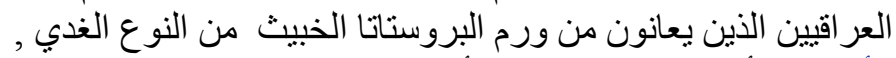

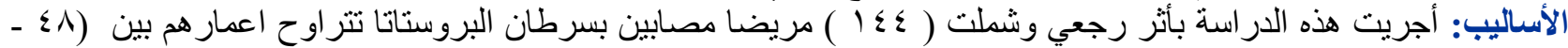

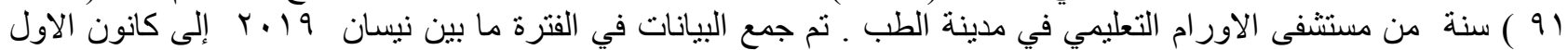

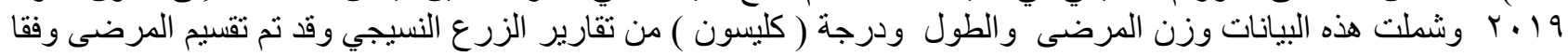
لمؤشر كتلة الجسم ومقارنة مع درجة مُنان معامل (كليسون). 


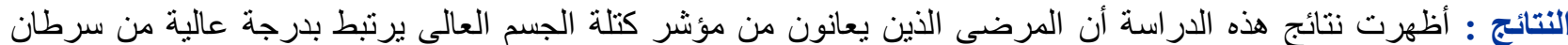

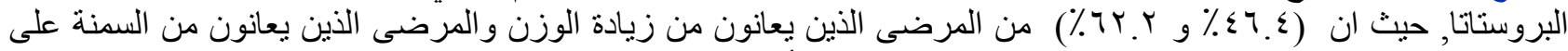

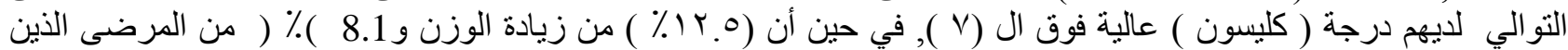

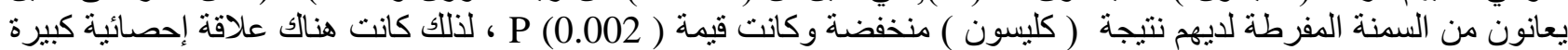

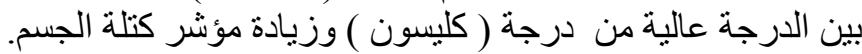
الاستثتاج : وجدت هذه الدراسة أن مؤشر كتلة الجسم العالي المرتبط بزيادة درجة عالية لمعامل ( كليسون ) لورم البروستاتا

الكلمات المفتاحية : معامل كتلة الجسم ، درجة كليسون ، ورم البروستات .

\section{INTRODUCTION}

\section{verview on prostate cancer :}

An estimated (1018) new cases of prostate cancer Were diagnosed in Iraq Accorrding to last Regestration in 2018 which is accounting ( $3.25 \%$ ) of all new cancer cases ${ }^{1}$ is the Fifth commonest cancer in male as shown in the table 1 below $^{2}$

Table 1 : Top Ten Cancer in Male, Iraq, $2018^{2}$

\begin{tabular}{|l|l|l|}
\hline $\begin{array}{l}\text { Top 10 cancer in } \\
\text { male }\end{array}$ & number & Percent \\
\hline Bronchus\&lung & 1830 & 13.44 \\
\hline Urinary bladder & 1173 & 8.62 \\
\hline leukemia & 1061 & 7.79 \\
\hline colorectal & 1023 & 7.52 \\
\hline prostate & 1018 & 7.48 \\
\hline $\begin{array}{l}\text { Brain and other } \\
\text { CNS }\end{array}$ & 820 & 6.02 \\
\hline $\begin{array}{l}\text { NonHodgkin } \\
\text { lymphoma }\end{array}$ & 680 & 5.00 \\
\hline Skin & 584 & 4.29 \\
\hline stomach & 524 & 3.85 \\
\hline pancreas & 413 & 3.03 \\
\hline Total Top Ten & 9126 & 67.04 \\
\hline
\end{tabular}

\section{Gleason Grade:}

The Gleason grading Has been proven as a reproducible system for adenocarcinoma of prostate, it is strongly associated with prognosis, and accepted worldwide, which assesses the architectural details of malignant glands under low to medium magnification. ${ }^{3}$ Five distinct patterns of growth from well to poorly differentiated were originally described by Gleason score using a scale from 1 to $5 .{ }^{4}$
Grade group 1 (Gleason score $\leq 6$ )

Grade group 2 (Gleason score $3+4=7$ )

Grade group 3 (Gleason score $4+3=7$ )

Grade group 4 (Gleason score $4+4=8$ )

Grade group 5 (Gleason scores 9 and 10)

\section{Obesity:}

As we all know the overweight and the obesity are associated with increased risk of at least 13 different types of cancer, however, still there is conflicting Data on the relationship between prostate cancer and the body weight. This is likely due to the different outcome measures used to define obesity, population differences, and other influential factors. ${ }^{5-7}$

Many observational studies have given evidence that even a $5-\mathrm{kg}$ (11 pound) increase in weight since early adulthood is associated with increased risk for overweight- and obesity-related cancers. $^{8}$ a $5-\mathrm{kg} / \mathrm{m}^{2}$ increase in BMI was associated with $20 \%$ higher prostate cancerspecific mortality. ${ }^{9}$

Obesity considers the second only to the tobacco smoking as a risk factor for all cancers, in regards to prostate cancer, obesity may lower the risk of low-grade indolent cancer, and increases the risk of high-grade aggressive prostate cancer . ${ }^{10}$

$\mathrm{BMI}$ is widely used as a marker for obesity, as it is easily measured, inexpensive, can be collected in the clinic and is available in most patient medical records or could be using self-reported weight and height, it is calculated by person's weight in kilograms divided by the square of height in meters, BMl grades is shown in table $2 .^{11}$

Table 2: Grade of BMl according to Body weight

\begin{tabular}{|l|l|}
\hline BMI & Weight Status \\
\hline Below 18.5 & Underweight \\
\hline $18.5-24.9$ & Normal or Healthy Weight \\
\hline $25.0-29.9$ & Over weight \\
\hline 30.0 and Above & Morbid obesity \\
\hline
\end{tabular}




\section{METHODS}

A cross-sectional study with retrospective analytical elements, prostate cancer patients who were diagnosed based on histopathological study and attended to the Oncology teaching hospital in Baghdad Medical City between the first of April to the first of December 2019 were included in this study.

\section{*Inclusion criteria:}

We included all patients with: Histopathologically proven Primary adenocarcioma of prostate.

\section{RESULTS}

A total number of 144patientswithprostatic cancer were enrolled in this study. The mean( $\pm S D)$ age of patients was $67.9( \pm 8.4)$ years, Ranging from between 48years-91 years.

$20(13.9 \%)$ of patients less than 60 years, 63 (43.8\%) of patients between $60-69$ years and 61 (42.4\% )of patients patients $\geq 70$ years, Figure 1 .

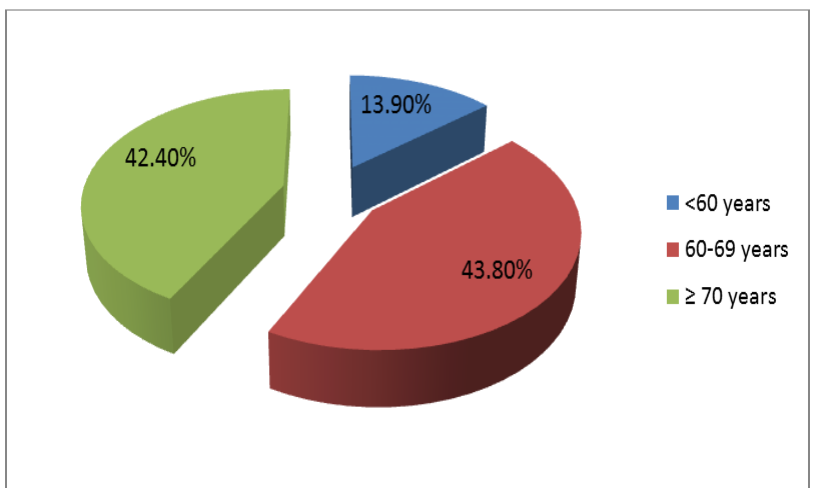

Figure 1: Distribution of patients by age groups

The mean $( \pm S D)$ body mass index $(\mathrm{BMI})$ was $26.9( \pm 4.5) \quad \mathrm{kg} / \mathrm{m}^{2}$, range between $19 \mathrm{~kg} / \mathrm{m}^{2}-$ $46 \mathrm{~kg} / \mathrm{m}^{2}$, the normal BMI was noticed in 51 $(35.4 \%)$ of patients, overweight was found in 56 (38.9\%) of patients and obesity was noticed in 37 ( $25.7 \%$ ) of patients Figure 2.

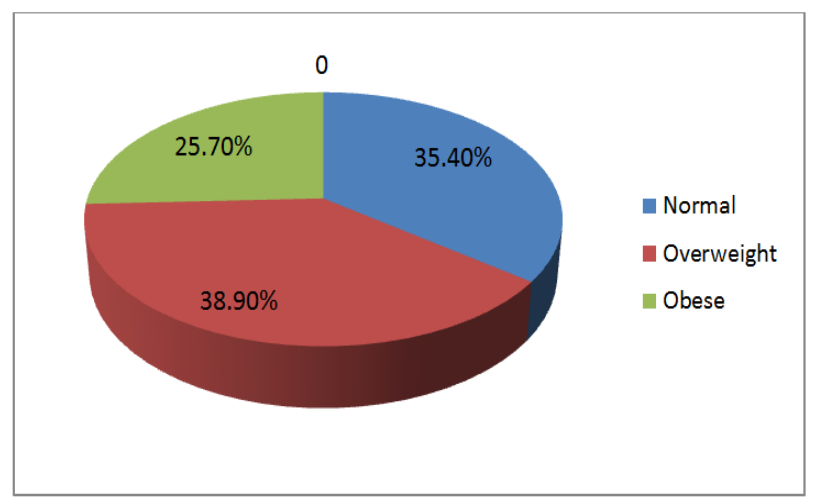

Figure 2 : Distribution of patients by BMI.
Gleason score was low score in $29(20.2 \%)$ of patients, intermediate score in 48 (33.3\%) of patients and high score in 67 (46.5\%) Table 3.

Table 3 : Gleason score for studied patients.

\begin{tabular}{|l|l|l|}
\hline \multicolumn{2}{|l|}{ Variable } & $\begin{array}{l}\text { Number and } \\
\text { percent }\end{array}$ \\
\hline \multirow{2}{*}{$\begin{array}{l}\text { Gleason } \\
\text { score }\end{array}$} & $\begin{array}{l}\text { Low }(<7) \\
(=7)\end{array}$ & $29(20.2 \%)$ \\
\cline { 2 - 3 } & Intermediate & $48(33.3 \%)$ \\
\cline { 2 - 3 } & High $(\geq 8)$ & $67(46.5 \%)$ \\
\hline
\end{tabular}

There was a significant difference in the mean $\mathrm{BMI}$ with different Gleason score $(p=0.002)$. While no association was found between the age and The age of prostatic cancer patients was not associated with Gleason score $(p=0.14)$. as in table 4 .

Table 4 : Relation of Gleason score with body mass index and Age.

\begin{tabular}{|c|c|c|c|c|c|}
\hline & & & eason sc & & \\
\hline & & Low & $\begin{array}{l}\text { Interme } \\
\text { diate }\end{array}$ & High & \\
\hline & $\begin{array}{l}\text { Norm } \\
\text { al }\end{array}$ & $\begin{array}{l}19(37.3 \\
\%)\end{array}$ & $\begin{array}{l}14(27.5 \\
\%)\end{array}$ & $\begin{array}{l}18(35.2 \\
\%)\end{array}$ & \\
\hline BMI & $\begin{array}{l}\text { Overw } \\
\text { eight }\end{array}$ & $\begin{array}{l}7(12.5 \\
\%)\end{array}$ & $\begin{array}{l}23(41.1 \\
\%)\end{array}$ & $\begin{array}{l}26(46.4 \\
\%)\end{array}$ & \\
\hline & Obese & $\begin{array}{l}3(8.1 \% \\
)\end{array}$ & $\begin{array}{l}11(29.7 \\
\%)\end{array}$ & $\begin{array}{l}23(62.2 \\
\%)\end{array}$ & $0.002^{*}$ \\
\hline $\begin{array}{l}\text { Mea } \\
\pm \text { SD }\end{array}$ & n BMI & $\begin{array}{l}24.4 \pm 3 \\
7\end{array}$ & $\begin{array}{l}27.1 \pm 3 \\
9\end{array}$ & $\begin{array}{l}27.8 \pm 4 . \\
8\end{array}$ & \\
\hline & $\begin{array}{l}<60 \\
\text { years }\end{array}$ & $3(15 \%)$ & $6(30 \%)$ & $\begin{array}{l}11(55 \\
\%)\end{array}$ & \\
\hline Age & $\begin{array}{l}60-69 \\
\text { years }\end{array}$ & $\begin{array}{l}10(15.9 \\
\%)\end{array}$ & $\begin{array}{l}21(33.3 \\
\%)\end{array}$ & $\begin{array}{l}32(50 \\
\%)\end{array}$ & \\
\hline & $\begin{array}{l}\geq 70 \\
\text { years }\end{array}$ & $\begin{array}{l}16(26.2 \\
\%)\end{array}$ & $\begin{array}{l}21(34.4 \\
\%)\end{array}$ & $\begin{array}{l}24(39.3 \\
\%)\end{array}$ & $0.14^{*}$ \\
\hline $\begin{array}{l}\text { Mea } \\
\pm S D\end{array}$ & n age & $\begin{array}{l}70.5 \pm 9 . \\
2\end{array}$ & $68 \pm 8.3$ & $66.8 \pm 8$ & \\
\hline
\end{tabular}


Logistic regression was done to find the predictive risk factor of high Gleason score cancer, after omitted the patients with intermediate Gleason score, the result showed that every increase in BMI by 0.203 there will be an increase in the risk to get high Gleason score cancer 1.22 time than low Gleason score cancer with $\mathrm{p}=$ 0.002 , Table 5 .

Table 5 : Logistic regression for high Gleason score cancer.

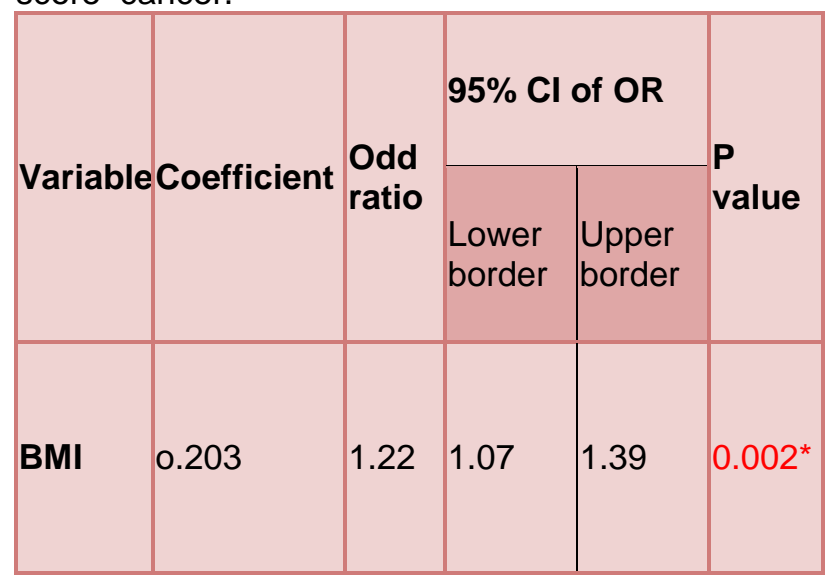

*significant $\leq 0.05$.

\section{DISCUSSION}

As the obesity is one of established risk factor for many cancers, and the prostate cancer is the most common non skin cancer worldwide, In our country is the Fifth commonest cancer affect Iraqi male according to Iraqi

Cancer Registry $2018^{2}$.

In this cross sectional study we found that high BMI associated with high grade of prostate cancer, as $(46.4 \%$ and $62.2 \%$ of overweight and obese patients respectively had high Gleason score above 7 ) while $12.5 \%$ of overweight and $8.1 \%$ of obese patients had low Gleason score . the $p$ Value was (0.002) so there was a significant statistic relation between high grade of Gleason score and high BMI.

This result was also observed in many previous studies, such as Research in Chinese population which had been published in August 2016 as a retrospective study; data from 290 patients, divided into two groups according to their BMI,(the high BMI group $\geq 25$; was 143 cases) and( low BMI group < 25; was 147 cases). From the high BMI group $44,76 \%$ had high Gleason score, which was more significant than the low BMI group ( $p$ value is 0.027 ) These results indicate that the rate of high Gleason score was greater in the high BMI group than the normal BMI group. ${ }^{12}$
Another large Research Article Results from the REDUCE Study in United States of America; was a 4-year, multicenter, double-blind, placebocontrolled study that showed the obesity was only associated with high grade histopathology. ${ }^{13}$

Many explanations have been put forward one of them is the overweight and the obesity might increase risk of cancer through induction of metabolic and endocrine abnormalities, More recent data suggest that the fat cells secrete hormones (leptin and adiponectin) that have influence on prostate cancer growth. ${ }^{14}$

Other theory try to explain that through increasing levels of insulin, insulin-like growth factor, and sex hormones, also the degree of inflammation in the fat cell contribute to aggressive prostate cancer . ${ }^{15}$

\section{CONCLUSION}

High body mass index was associated with increse incidence of high Gleason grade of adenocarcinoma of prostate cancer .

\section{REFERENCE}

1. Obeyed HH , Al Ibraheemi A, Ali KM , et al., Iraqi Cancer Regesitry Annual Report,Iraqi Cancer Board, Republic of Iraq;2018 P.49.

2. Obeyed HH , Al Ibraheemi A , Ali KM , et al.,Iraqi Cancer Regesitry Annual Report,Iraqi Cancer Board, Republic of Iraq;2018 P.50.

3. Bulten W, Pinckaers $H$, van Boven $H$, Vink R, de Bel T, van Ginneken B, et al. Automated deeplearning system for Gleason grading of prostate cancer using biopsies: a diagnostic study. The Lancet Oncology. 2020 Feb 1;21(2):233-41. DOI: 10.1016/S1470-2045(19)30739-9

4. Madabhushi A, Feldman MD, Leo P. Deeplearning approaches for Gleason grading of prostate biopsies. The Lancet Oncology. 2020 Feb 1;21(2):187-9. DOI: 10.1016/S14702045(19)30793-4

5.Calle EE, Kaaks R. Overweight, obesity and cancer: epidemiological evidence and proposed mechanisms. Nat Rev Cancer 2004;4:579-91. DOI: $10.1038 / \mathrm{nrc} 1408$

6. Presti JC Jr. Obesity and prostate cancer. Urol 2005;15:13-6. DOI: 10.1097/00042307200501000-00004

7.Amling CL. Relationship between obesity and prostate cancer. CurrOpin Urol 2005;15:167-71. doi: 10.1097/01.mou.0000165550.94663.fb

8. keum N, Greenwood DC, Lee DH, Kim D, Aune $\mathrm{D}$, Ju W, et al.Adult weight gain and adiposityrelated cancer:a dose -response meta-analysis prospective observationl studies.J Natl cancer Inst 2015;107:djv088. DOI: 10.1093/jnci/djv088 
9. Cao Y, Ma J. Body mass index, prostate cancerspecific mortality, and biochemical recurrence: a systematic review and meta-analysis. Cancer Prev Res (Phila). 2011;4:486-501. DOI: 10.1158/1940-6207.CAPR-10-0229

10. Buschemeyer WC 3rd, Freedland SJ. Obesity and prostate cancer: epidemiology and clinical implications. European urology. 2007; 52:33143. [PubMed: 17507151]. DOI: 10.1016/j.eururo.2007.04.069

11. Stensland SH, Margolis S. Simplifying the calculation of body mass index for quick reference. Journal of the American Dietetic Association. 1990;90(6). doi: 10.1080/08035250500334738.

12. Zhou F, Chen X, Pu J, Ouyang J, Li G, Ping J, Lu Y, Hou J, Han Y. Correlation between body mass index (BMI) and the Gleason score of prostate biopsies in Chinese population. Oncotarget. 2016 Sep 27;7(39):63338. doi: 10.18632/oncotarget.11453

13. Vidal AC, Howard LE, Moreira DM, CastroSanta maria R, Andriole GL, Freedland SJ. Obesity increases the risk for high-grade prostate cancer: results from the REDUCE study. Cancer Epidemiology and Prevention Biomarkers. 2014 Dec 1;23(12):2936-42. DOI: 10.1158/1055-9965.EPI-14-

0795 Published December 2014

14. Renehan AG, Zwahlen M, EggerM Adiopsity and cancer risk; new mechanistic insight from epidemiology.Nat Rev Cancer 2015, 15 484-98 DOI: $10.1038 /$ nrc3967

15. Mistry T, Digby JE, Desai KM, Randeva HS. Obesity and prostate cancer: a role for adipokines. Eur Urol 2007;52:46-53.Doi: 10.1016/j.eururo.2007.03.054. Epub 2007 Mar 26. 